\title{
Shaping the Education to Meet the Global Demands: Industrial Inclusiveness in University Curriculum
}

\author{
Lalith Edirisinghe ${ }^{1}$, Sampath Siriwardena ${ }^{1} \&$ Lakshmi Ranwala $^{1}$ \\ ${ }^{1}$ Faculty of Management and Social Sciences/ CINEC Campus, Sri Lanka \\ Correspondence: Lalith Edirisinghe, Faculty of Management and Social Sciences/ CINEC Campus, Sri Lanka. Tel: \\ 9-477-756-2505. E-mail: lalith.edirisinghe@cinec.edu
}

Received: September 26, 2021 Accepted: October 6, 2021 Online Published: November 6, 2021

The research is financed by Accelerating Higher Education Expansion and Development (AHEAD) which is a World Bank funded Sri Lankan government operation to support the higher education.

\begin{abstract}
The world entered to knowledge-based economy which is based on the production and use of information. Today computer technology, language proficiency and logistics play a major role. University Curriculum connects the secondary level education and the industry. Therefore, industry inclusiveness is essential in transforming children to an industry worker or an entrepreneur. This paper is derived from an opinion survey, desk research, and a case study. Reports of international institutions were studied extensively in the literatures survey. The respondents of the survey consisted key personnel in the government and private sector covering a cross section of the stakeholders in education and business world. The report analyses are then evaluated and discussed though a case study in Sri Lanka. The practices and procedures in the contemporary education system in the country is systematically explained in this section. The report presents its key recommendation under seven areas as policy recommendations. It includes innovative concepts such as, vertical integration between schools, universities, and industry; extended academic disciplines at tertiary level; changes in the university; review to selection criteria of state universities; new academic disciplines in the school curriculum; technical and vocational education; focus on children with different skills etc.
\end{abstract}

Keywords: education, university, industry, curriculum, integration, development

\section{Introduction}

Education is fundamental to improving human lives and living standards, boosting competitiveness in an economy, and achieving inclusion and social mobility (IFC, 2017). The Sustainable Development Goals (SDGs) constitute the core of the 2030 Agenda for Sustainable Development, the new development framework that marks a paradigm shift in the global framework for development. According to UNIDO, (2015) it seeks to transform the world and will guide all global, regional, and national development endeavors for the next 10 years. SDG's presents a unique opportunity to reorient efforts towards a new path for development with sustainability at its core (Osman, et al., 2017). Industrial inclusiveness becomes vital in the university curriculum (and the whole education system wherever possible) to integrate the society and the industry. Tertiary education is both the aspiration of more and more young people around the globe and a fundamental requirement for employment in the industries that drive the global knowledge economy (The World Bank, 2021).

Technological change and innovation drive the development of the knowledge-based economy through their effects on production methods, consumption patterns and the structure of economies (OECD, 2001). Therefore, the knowledge economy is based on the production and use of information which makes the computer technology and language proficiency are fundamental prerequisites. In a highly competitive globalized environment, the logistics also play a major role in the knowledge economy. This keeps evolving with the possibilities opened through technological change. This paper investigates the way forward for shaping the education system to meet evolving global demands combining all these factors. Education for sustainable development (ESD) is regarded as a key element of high-quality education (UNESCO, 2019). University Curriculum plays the midpoint role connecting the secondary level education and the industry. The industry inclusiveness should provide a boost to the transformation of children to an industry worker or an entrepreneur. In Education, curriculum is referred to a systematic sequence based on the set standards of planned experiences. Up on delivering the course students learn 
and practice to achieve proficiency.

Inclusiveness refers to the practice or policy of providing equal access to opportunities and resources for people who might otherwise be excluded or marginalized. Therefore, it not only facilitates a transformation of individual but the generation and the society. Education is central to this and to the achievement of all 17 Sustainable Development Goals (SDGs). Education directly relates to one goal (SDG 4) but cuts across the entire SDG agenda. (Osman, et al., 2017). A well-managed, strategically oriented, diversified and articulated tertiary education system is vital for producing the caliber and diversity of graduates needed both for the economy that exists today and for economy to which a nation aspires (The World Bank, 2021). This paper discusses the industrial inclusiveness in university curriculum (IUC) to shape the education system in a country with the objective of meeting the evolving and transforming global demands for developing, upskilling, and reskilling young generation. Higher education can be shaped as a public good and as a driver of social and economic development of countries and regions (UNESCO IESALC, 2021).

\section{Research Methodology}

The research approach of this paper is a combination of opinion survey and desk research. Initially, convenient sample of thirty-eight opinion leaders representing all stakeholders of the education sector have been identified. A comprehensive literature survey was done simultaneously, and semi structured questionnaire was designed based on the previous research. Contemporary reports and analysis of international institutions such as International Bank for Reconstruction and Development (IBRD); The World Bank; United National Industrial Development Organization (UNIDO); World Economic Forum (WEF); United Nations Educational, Scientific and Cultural Organization (UNESCO) were studied extensively to compare various trend and opinions. A case study was done to better understand if the global analysis is commensurate with the reality in the context of Sri Lanka and to ascertain how far it can be helpful in the way forward. Reports of Department of Census and Statistics, University Grants Commission, Central Bank of Sri Lanka etc. have been referred to evaluate comments received in the interview process.

The respondents of the survey consisted secretaries to leading ministries in Sri Lanka, Vice chancellors, Deans of various faculties in private and government universities, school principal and senior teachers, presidents of industry associations, officers of carrier development unit of higher education institutes, representatives from a university alumni, current students, senior lecturers, Chairmen, CEO's and General Managers, HR managers of leading firms covering both private, and public sectors. A qualitative analysis was administered to the response of structured sections of questionnaires. Non structed sections was compiled based on most relevant areas for the study.

\section{Shaping the Education}

\subsection{Education}

The Education is not just about knowledge acquisition or skills development but may associate with direct and indirect transformative influences in the society. It is vital for the development of human beings and quality of life. As such, tertiary education provides unique opportunities for individual development and equality of opportunity as well as promoting shared prosperity (The World Bank, 2021). Recent sociological rational choice theories argue that educational decisions are made with the objective of maximizing both economic and social returns to education (Jæger, 2007).

Today, more people than ever before are participating in a wide range of educational programmes offered by both public and private providers. As a result, there has been increasing focus on the balance between public and private funding of education. Education is considered a service in marketing context. Therefore, private sector participation in a particular subject area will depend on the commercial returns of conducting programs of that nature. The utility the respective client namely, students gain is the key for the sustainability of private education institutes. Within economics, the concept of utility is a measure of pleasure or happiness within the theory of utilitarianism by moral philosophers. It has been defined subsequently as a personal choice rather than the pleasure received. In anyway, education seen as a non-utility function like administering medicine to cure a disease what could be experienced in the society. Therefore, the expected economic or financial returns after completion of educational program are the real motivator of education. And the selection of the education stream may largely influence on those expectations. The governments may consider the type of subjects that adds value to the society than the return on investment. However, in the current economic environment, many governments are finding it difficult to provide the necessary resources to support this increased demand for education through public funds alone (OECD, 2019). Considering this overall background of the education industry the approach is highly complicated and sensitive. 


\subsection{Teaching}

According to UNESCO, (2021) one of the key factors of high-quality teaching is the teacher highlights learning through doing to increase the student's competitiveness in the job fair. The other factors include, (i) The teacher has passion for teaching, (ii) the teacher pays attention to the student's independent learning ability, (iii) the teacher intrigues student's interest in learning, (iv) the teacher places emphasis on furnishing the student with professionalism and confidence, and (v) the teacher reviews teaching effectiveness and makes progress in pursuing the value of high-quality. From providing skills for immediate professional application to building stages of complexity of learning toward postgraduate studies and research, tertiary education offers limitless avenues for social mobility and economic development (The World Bank, 2021). However, in many developing countries students have no proper awareness about selecting their education path in a productive manner thus ensure systematic development of knowledge, accumulation of skills and competence built upon synergy of total time spent of learning. In other words, they have no way of taking a learned decision unless they consult the right educationist. Such qualified persons are rare and not freely or conveniently available. According to World Economic Forum, $65 \%$ of children entering primary school will ultimately end up working in completely new job types. The employment landscape is rapidly evolving thus the ability to anticipate and prepare for future skills requirements, job content and the aggregate effect on employment is increasingly critical (WEF, 2016). It may be very useful to establish human capital agendas for individual countries. Accordingly, top sectors of the country can focus on describing how demand for the supply of skilled workers will develop in the years ahead. The agendas can be used to help shape vocational and higher professional education in the future (Ministry of General Affairs, 2021). The OECD Learning Framework 2030 offers a vision and some underpinning principles for the future of education system. It is about orientation, not prescription. The learning framework has been co-created for the OECD Education 2030 project by government representatives and a growing community of partners, including thought leaders, experts, school networks, school leaders, teachers, students and youth groups, parents, universities, local organizations, and social partners (OECD, 2018).

The knowledge and skills of workers available in the labor supply is a key determinant for both business and economic growth. The general perception is that the industries with higher education and training requirements tend to pay workers higher wages. However, the respective discipline that the education has been secured play a key role in this (Radcliffe, 2021). For example, a degree in art subjects many do not get similar recognition like a science graduate. The quality of training may be significantly different between developed and developing countries. An economy's productivity rises as the number of educated workers increases since skilled workers can perform tasks more efficiently. This new educational model based on use education for the SDGs achievement generates a challenge in education management because it is necessary to reorient curriculum, programs, practices, and policies. This challenge affects the governance of education, educational institutions managers and educators, as well as the content and pedagogy of education (Ferrer-Est'evez \& Chalmeta, 2021).

\section{Global Demands}

\subsection{Transformation of Knowledge, Skills, and Competence}

Government institutions and private sector employers are taking steps to get more trained technical workers into the workforce. Considering the substantial involvement of the technology such as information communication technology in the business process, it is necessary to secure required knowledge, skills, and competence (KSC) through the formal education system or professional training. However, if the formal education is vertically integrated with the industry requirements the potential employees will develop their KSC more objectively to carry out the tasks efficiently and effectively thus productivity of the firm will be high.

Businesses require labor and capital as inputs to their production process. Changes in the marginal productivity of labor is one of the reasons for a shift in labor demand. The productivity usually has a correlation with the knowledge, skills, and competence of employee while other factors such as technological advances, improvements in logistics etc. can influence the overall output. However, even in highly sophisticated manufacturing process the KSC plays a vital role in different perspectives. For example, if a firm convert their manual operation to a hightech production line the demands for education and training changes drastically. In other words, industrial inclusiveness at some level of education is a must. In most countries this happens at the tertiary level education. Therefore, the university curriculum becomes a vital component developing right people to right jobs through forming a systematic value chain. This is the most invited vertical integration that needs in the current social system and it is long awaited in the developing countries.

To adapt and maintain competitiveness in response to changing consumer preferences and technological change, companies need appropriate organizational structures, a skilled workforce and able management (OECD, 2001). 
The global customer is becoming more quality oriented. While the quantity demanded of products are increasing consumers want product personalization too. Responding quickly to changing customer needs is a real challenge in any business. This can be only won by systematically developed skilled workforce with appealing mindset. The knowledge, skills and competence of the person joining the workforce needs to be vertically integrated and this process should be strategically managed and continuously improved. Structural transformation towards inclusive and sustainable industrial development serves as an engine to create the competitive job opportunities that are needed today in both developed and developing countries (UNIDO, 2015).

\subsection{Changing Industry Culture}

From the industry perspectives a four-year degree has become compulsory for nearly every job as many value additions are required to offer a quality service to modern customers. Collaboration between government authorities and private education institutes can play a substantial role by expanding the current scope (Edirisinghe, et al., 2017). Certain job categories have been identified as highly demanding although it depends on the country and its economy. In general, Health Science, Healthcare Administration, Psychology and Pharmacology have been in the forefronts. Similarly, Computer Science, Information Technology and Data Analytics too play a major role in the present context. Post Covid 19 scenario has created a huge demand for virtual business models especially in education sector and E commerce. Engineering jobs have been evolving and will continue to evolve. In today's context the organizations focus on selling the features and functions of their products rather than value and differentiation cannot sustain. With the supply chain is becoming more complicated and diverse disciplines such as Business Administration, Human Resources management, Finance, Logistics, and Marketing are seen more demanding. Mathematics and statistics are another two sectors that gained momentum in the recent past. By positioning industries at the right stage of value chains and markets, countries can benefit from opportunities offered by global trade, including more jobs, exports, economic security, and foreign direct investment (UNIDO, 2015). These developments have obviously created a substantial demand for jobs in the Education sector. When the customers are left with many options given the increasing global competition the quantity is no more a satisfier, it is only the quality of jobs that counts for the sustainability of a firm.

As higher education increases the KSC level, it also may improve the productivity of the individual. As a result, such individuals are paid a higher wage in the labor market. Also, higher skilled individuals qualify for different types of jobs than lower skilled individuals. High skilled jobs often offer various fringe benefits, which are not paid as money, but which are all equivalent to a wage increase (Alstadsæter, 2004). The challenge for businesses, and governments to fully seize the opportunities Overall, there is a modestly positive outlook for employment across most industries, with jobs growth expected in several sectors. However, it is also clear that this need for more talent in certain job categories is accompanied by high skills instability across all job categories (WEF, 2016). More qualified technicians and skilled technical workers are in great demand in any country. But the common issue is that they are in short supply in most cases. This is especially true in top sectors like life sciences and health, chemicals, and high tech (Ministry of General Affairs, 2021). Generally, the industry specific subjects are taught at the university education after successful completion of the secondary level which has common subjects such as mathematics, science, language proficiency, commerce, religion etc. The field of secondary vocational education has several Centers for Innovative Skills dedicated to improving the links between education and the labor market. For institutions for higher professional education (HBO), these are the Centers of Expertise. The aim is for the centers to develop into international centers of knowledge that attract the most talented students and the best teachers (Ministry of General Affairs, 2021)

Tertiary education derived with the terms "higher education", or "post-secondary education" where it refers to "a level of education which is beyond the secondary education, undertakes in tertiary education institutions but in a wide variety of other settings, including in secondary schools. At works, via free-standing, information technologybased offering and a host of private and public entities." (Whitman, 2003, p. 191). There is a rapid growth in the enrolment of tertiary level education in developing countries all over the world after the independence (Salmi \& Bassett, 2014). Also stated that the due to the expansion of primary and secondary education in many countries has contributed to the increasing demand of tertiary education sectors. Furthermore, stated that the increased demand for the tertiary education result from the greater proportion of students of high socio-economic status. According to the findings, there should be a well efficient financial aid to remove the financial barriers for the enrolment to the tertiary education and the specified barriers can be mitigate by low fees, student loans and grants. Also stated that there are many outreach programs has implemented to secondary schools and retention programs to improve the completion rates. Furthermore, it was highlighted that, there is not any mechanism that has considered to overcome the barriers as to the best, to have a success in tertiary education with one directive policy. 


\section{Industrial Inclusiveness in The Education System (IIES)}

United Nations proposed the Sustainable Development Goals (SDGs) in 2015, to achieve the harmony and shared prosperity between humans and the Earth, and advocate for fair and high-quality education (UNESCO, 2021). Education is fundamental in achieving the Sustainable Development Goals (SDGs). It identifies learning objectives, suggests topics and learning activities for each SDG, and describes implementation on different levels from course design to national strategies (Rieckmann, et al., 2017). Education is an indispensable component in development and growth of a country. The human mind makes possible all other development achievements, from health advances and agricultural innovation to infrastructure construction and private sector growth (IBRD-WB, 2011). Therefore, it is the responsibility of policymakers in any country to ensure the systematic flow of educating its population with relevant subject knowledge is laid down and make it accessible to all. UNESCO, (2021) proposes seven categories about the effectiveness of high-quality teaching namely, (i) Faith in sustainability in teaching, (ii) the trend of talent demand, (iii) the teaching value of sustainability, iv) curriculum mapping, (v) teaching approach, (vi) teaching evaluation, and (vii) sustainable management of teaching development. It is plainly visible from above that the trend of talent demand, curriculum mapping and sustainable management of teaching development are the fundamental drivers of shaping the education to meet global demands and establish industrial inclusiveness in the education system (IIES).

According to the marginal decision rule a profit-maximizing entity will opt for additional units of labor if the extra output that is produced by hiring one more unit of labor adds more to total revenue than it adds to the total cost. In a highly competitive environment, the first option be the maximization of productivity of existing employees. This needs upskilling or reskilling though training and development. Developed countries usually higher people with highest educational qualifications. It is possible to higher qualified people in relevant disciplines if the education system in the country produces them in a sustainable manner. It is a management process rather than one time activity. The Firms in that country will increase profit by increasing its use of labor. Therefore, it is fair that the higher the KSC the higher the renumeration a firm can allocate. Fringe benefits and the wage premium constitute the pecuniary return to higher education. The individual specific nonpecuniary return to higher education is the intrinsic or the consumption value of education, which is defined in section (Alstadsæter, 2004).

The rapidly changing demands of the job market are outpacing university reforms .Government of Netherlands states, entrepreneurs are vital for economic growth. This should be reflected in an education system that teaches entrepreneurial skills (Ministry of General Affairs, 2021). It further reiterates that Teaching entrepreneurial skills; Combining studying with running a business; Better links between education and the labor market; and More qualified technicians are the key contributors. Creating an entrepreneur means creating many job opportunities and increasing global production in an innovative manner. Government institutions and private sector employers are taking steps to get more trained technical workers into the workforce. Considering the substantial involvement of the technology such as information communication technology in the business process, it is necessary to secure required knowledge, skills, and competence (KSC) through the formal education system or professional training. However, if the formal education is vertically integrated with the industry requirements the potential employees

\section{Case Study}

This case study was conducted in Sri Lanka. The University of Ceylon was established in 1942 by the Ceylon University Ordinance No. 20 of 1942. The university was in Colombo and the second campus was built in Peradeniya. The University of Ceylon became the University of Sri Lanka with the University of Ceylon Act No. 1 of 1972 resulting in a centralized government control. It paved the way for separate universities. According to the Universities Act No. 16 of 1978 new universities of independent identities were created but the state controlled through the University Grants Commission (UGC). Amendments to the University Act made in 1999 allowed state universities and private institutes to grant undergraduate and postgraduate degrees. The quality and competence of undergraduates in Sri Lanka currently varies considerably. At the high-end, graduates are globally employable. However, the lower end graduates struggle to find suitable employment. These differences reflect sharp variations in the quality of performance and the socio-emotional skills (employability skills) of students. Therefore, tertiary education should not only focus on skills and abilities of the graduates but also how the students may feel about the educational experience.

The term "Customer" in tertiary education is quite different from that of manufacturing or other general service sector. In Sri Lanka the course fees of a fulltime undergraduate are paid by the parents. Therefore, the private sector education provider should satisfy the expectation of the consumer (student) and the client (parents). At present, Tertiary education is going in the direction of commercial competition. Private sector is lack of funding from government thus tertiary education institutions must find their finances through private sources. The degree 
programs that are taught in the university should be decided based on the due considerations real demands in the industry. This could be done through proper consultative procedure with the stakeholders in the respective industries. In other words, better results could be achieved by applying the concept of marketing in a comprehensive manner. The marketing is defined as the management process responsible for identifying, anticipating, and satisfying customer requirements profitably (CIM, 2015). Therefore,

Employability Survey Report 2017 of Wayamba University of Sri Lanka (ESR - WUSL) reports that employability status of the graduates at the general convocation of 2017. According to this report an average of 37 percent of unemployed graduates in 12 departments were there at the time of the survey. It should be seriously noted that these graduates have failed to contribute to the economy not because of their fault but due to the unsupportive education system. Given these statistics, it is evident that there is no return on investment from the most intelligent and qualified young talent of the country. If the country produces more and more unemployed gradates, the ultimate impact to the economy and society will be unbearable. This will lead to critical psychological repercussions unless a systematic approach is introduced through a scientific research. Gradual increase of unemployed graduates can be observed from 2014 and 2017 and was reported as 38\% in 2017).

It is reported more than 12,000 Sri Lankan students go overseas annually for higher education opportunities. This shows the present education service providers have failed to cater to the demand within the country. The drain on foreign exchange is estimated more than $\$ 50$ million per annum (Edirisinghe, 2020) which is a developing small country like Sri Lanka is a substantial waste. Accelerating Higher Education Expansion and Development (AHEAD) Ministry of Higher Education recognizes, in its objective of results area 1, to increase enrolment in higher education programs of strategic importance for economic development. It is true, in the past, students were victims of circumstance that is due to the infrastructure and resources limitations for state universities.

A Total of approximately 300,000 students sit GCE A/L exams in the local streams and nearly 180,000 obtain minimum qualification to enter state university. It is not the student who select their education stream in universities in the current practice but the state authorities namely, University Grants Commission. The students with highest $Z$ scores in the respective year will be selected to the state universities. In Sri Lanka, less than 30,000 students per year are fortunate to get free education beyond the secondary level. (Technically, there is no free education though in Sri Lanka because the state university education is facilitated by the taxpayers in the country thus it comes at a price). However, the outcome is devastating as there are considerable numbers of unemployed graduates already in the country. It was reported that there were 57,000 unemployed graduates as of 31 December 2016 and this number may have increased by now in the same proportion. Governments time to time offer these graduates jobs in the state sector, However, the question remains that whether these candidates are "work ready" to be absorbed to any industry. The theoretical knowledge they gained during their four years at the university will become a waste if they cannot contribute that knowledge effectively. This trend shows the indispensable need for vertical integration between the school, university, and the industry.

The rest (approximately 150,000) of the students of those who obtain minimum entry qualification for university education (and are rejected by the state university system) are compelled to spend substantial money on tertiary education every year. This money is either spent domestically or overseas. Or they are deprived of their tertiary education despite being qualified to follow a degree program. This is an unfair practice of discrimination. If students travel overseas, huge sum of foreign exchange is spent on tuition fee and overseas stay. Even if the students follow a degree awarded by a foreign university while studying in Sri Lanka the foreign exchange is drained through royalty fee and other affiliation charges. But now with the availability of multiple options offered by international universities and local non state higher education institutes students have many choices. and more encouragingly, the approach of the non-state sector is comparatively more vibrant, differentiated and updated in their degree offers due to commercial mindset and competition. The above two scenarios namely, government education system and private sector participation at the tertiary level explain how they jointly cater to two different segments. Therefore, guiding students in the right direction for their tertiary education is timely and becoming more critical than ever before. Generic employability skills are important because the labor market is intensely competitive, and employers are looking for people who are flexible, take the initiative and can undertake a variety of tasks in different environments.

In the recent years more students start entering tertiary education due to increased options available. In addition to the degree programs offered by foreign universities, non-state higher education institutes commenced diversified and marketable degree programs approved by University Grants commission and Ministry of Higher Education. Therefore, several graduates are going to increase significantly in the coming years. In addition, the Interest Free Loan Scheme (IFLS) introduced by the government facilitates many students to enter non-state higher education institute that has many options under various academic disciplines. This trend will lead to heavy competition for 
graduate employment in the coming years unless the students are guided properly to select the right educational scheme. In Sri Lanka, children are influenced by their parents, not only in the marriage but, also in selecting the secondary and tertiary education scheme. However, it is somewhat uncertain whether the parents have the right knowledge about the job market at the time the students are graduated. Therefore, it is timely that the students develop necessary competence in the choice of tertiary education scheme.

Private sector provides a greater share of education services does not eliminate the need for the government to play a stewardship role to ensure that all children have access to a quality education. The government's role in setting up an effective regulatory environment is paramount (Lewis, 2013). During the last two decades following the amendments to the University Act, a few private institutes got the permission to grant degrees. Through these options the youth get new avenues reducing unrest and unemployment. With all new introductions, still there are unemployed graduates mainly holding arts degrees. All graduates from the fields of medicine, information technology, commerce, law, and engineering disciplines however are employed. That raises the focus of this policy proposal. 15 university eminent persons from the higher education sector were interviewed as part of this research. They include Deans, Heads of Departments, Professors, and high officials of the ministry of Higher Education and the UGC. In addition, 12 students who sat for GCE AL examination in 2019 and 12 parents whose children sat the same examination were interviewed.

Sri Lanka is falling behind many of the other countries that are progressing at a very rapid level especially in Science and Technology and skill development. Sri Lanka lacks a framework or mechanism for university selection based on students' qualifications, skills, or choice (Ranwala, et al., 2020) . Accelerating Higher Education Expansion and Development (AHEAD) Ministry of Higher recognizes, in its objective of results area 1, to increase enrolment in higher education programs of strategic importance for economic development. Employability Survey Report 2017 of Wayamba University of Sri Lanka (ESR - WUSL) reports that employability status of the graduates at the general convocation of 2017. According to this report average 37 percent of unemployed graduates in 12 departments at the time of the survey.

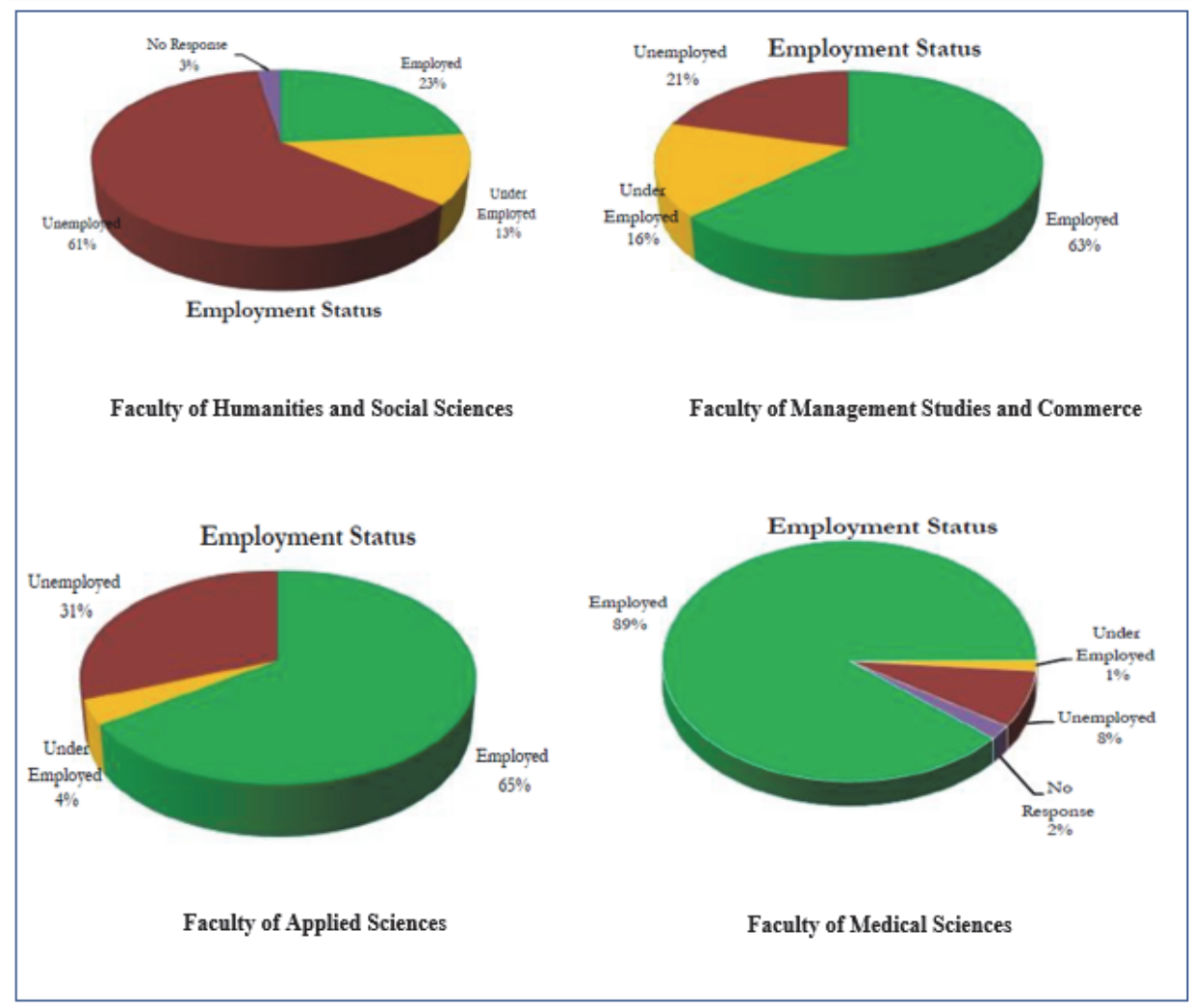

Figure 1. Variance of unemployment in faculties at University of Sri Jayawardenapura

(Data Source: HETC)

The rest (approximately 150,000) of the students of those who obtain minimum entry qualification for university education (and are rejected by the state university system) are compelled to spend substantial money on tertiary 
education every year. This money is either spent domestically or overseas. Or they are deprived of their tertiary education despite being qualified to follow a degree program. This is an unfair practice of discrimination. If students travel overseas, huge sum of foreign exchange is spent on tuition fee and overseas stay. Even if the students follow a degree awarded by a foreign university while studying in Sri Lanka the foreign exchange is drained through royalty fee and other affiliation charges. This scenario badly impact on the country's economic condition and requires systematic approach (Edirisinghe, 2018). But now with the availability of multiple options offered by international universities and local non state higher education institutes students have many choices. and more encouragingly, the approach of the non-state sector is comparatively more vibrant, differentiated and updated in their degree offers due to commercial mindset and competition. The above two scenarios namely, government education system and private sector participation at the tertiary level explain how they jointly cater to two different segments. Therefore, guiding students in the right direction for their tertiary education is timely and becoming more critical than ever before. Generic employability skills are important because the labor market is intensely competitive, and employers are looking for people who are flexible, take the initiative and can undertake a variety of tasks in different environments.

In the recent years more students start entering tertiary education due to increased options available. In addition to the degree programs offered by foreign universities, non-state higher education institutes commenced diversified and marketable degree programs approved by University Grants commission and Ministry of Higher Education. Therefore, several graduates are going to increase significantly in the coming years. In addition, the Interest Free Loan Scheme (IFLS) introduced by the government facilitates many students to enter non-state higher education institute that has many options under various academic disciplines. This trend will lead to heavy competition for graduate employment in the coming years unless the students are guided properly to select the right educational scheme. In Sri Lanka, children are influenced by their parents, not only in the marriage but, also in selecting the secondary and tertiary education scheme. However, it is somewhat uncertain whether the parents have the right knowledge about the job market at the time the students are graduated. Therefore, it is timely that the students develop necessary competence in the choice of tertiary education scheme.

Non state universities enroll students after state universities complete their selections based on merit. There is a fierce competition among these institutions to secure their share from those who failed to earn a slot for free education in state universities (Edirisinghe, et al., 2018). Private sector provides a greater share of education services does not eliminate the need for the government to play a stewardship role to ensure that all children have access to a quality education. The government's role in setting up an effective regulatory environment is paramount (Lewis, 2013). During the last two decades following the amendments to the University Act, a few private institutes got the permission to grant degrees. Through these options the youth get new avenues reducing unrest and unemployment. With all new introductions, still there are unemployed graduates mainly holding arts degrees. All graduates from the fields of medicine, information technology, commerce, law, and engineering disciplines however are employed. That raises the focus of this policy proposal. It was noted 15 university eminent persons from the higher education sector were interviewed as part of this research. They include Deans, Heads of Departments, Professors, and high officials of the ministry of Higher Education and the UGC. In addition, 12 students who sat for GCE AL examination in 2019 and 12 parents whose children sat the same examination were interviewed.

Sri Lanka is falling behind many of the other countries that are progressing at a very rapid level especially in Science and Technology and skill development.

Table 1. Gradate Unemployment in 12 departments

\begin{tabular}{llccc}
\hline & Department & $\begin{array}{c}\text { Total graduated } \\
\mathbf{2 0 1 7}\end{array}$ & $\begin{array}{c}\text { Unemploye } \\
\text { d }\end{array}$ & $\begin{array}{c}\text { Unemployed } \\
\text { percentage }\end{array}$ \\
\hline $\mathbf{1}$ & Agribusiness Management & 25 & 13 & 52 \\
$\mathbf{2}$ & Business Management & 202 & 97 & 48 \\
$\mathbf{3}$ & Horticulture \& $\quad$ Landscape & 36 & 16 & 44 \\
& Gardening & & & \\
$\mathbf{4}$ & Plantation Management & 36 & 15 & 42 \\
$\mathbf{5}$ & Applied Nutrition & 22 & 8 & 36 \\
$\mathbf{6}$ & Banking \& Finance & 42 & 13 & 31 \\
$\mathbf{7}$ & Accountancy & 162 & 47 & 29 \\
$\mathbf{8}$ & Biotechnology & 16 & 4 & 25 \\
\hline
\end{tabular}




\begin{tabular}{llccc}
\hline $\mathbf{9}$ & Aquaculture \& Fisheries & 17 & 4 & 24 \\
$\mathbf{1}$ & Insurance \& Valuation & 10 & 2 & 20 \\
$\mathbf{0}$ & & & 3 & 16 \\
$\mathbf{1 1}$ & Livestock \& Avian Sciences & 19 & 4 & 13 \\
$\mathbf{1}$ & Food Science \& Technology & 31 & & 37 \\
$\mathbf{2}$ & & & 226 & \\
\hline
\end{tabular}

Data Source: ESR - WUSL (2017)

\section{Conclusions}

According to the desk research and comments by respondents who are the representatives of key stakeholders of the education sector following conclusions and recommendations are made. The findings of the case study also were helpful in the process.

The industrial inclusiveness in university curriculum (IUC) is essential to shape the education system in a country to achieve objectives of its development agenda. The university curriculum must be instrumental in capturing the evolving and transforming global demands for developing, upskilling, and reskilling of young generation. However, this is only one aspect in shaping the education to meet the global demands. The industrial inclusiveness in university curriculum should be well supported by the vertical integration between school, university, and the industry. Accordingly, the students are aware of the academic path leading to their future career destination. The key industries that are crucial in the country's development agenda should be identified at policy level and close interaction is recommended with its stakeholders. As this is a long process the policy makers must make a priority list of the industries that are required to be integrated with the education system based on country's social, economic, and technological status and advancements.

Accordingly following recommendations are made.

1. Initiate vertical integration between schools and State/private universities

2. Expand the horizon of academic disciplines to students at tertiary level

3. Make necessary changes in the university curriculum facilitating development, upskilling, and reskilling human resources of the country

4. A review to selection criteria of state university entrance if applicable

5. Introduce evolving new academic disciplines in the school curriculum

6. Further technical and vocational education is also encouraged at tertiary level depending on the demand from industry

7. Formally recognize and appreciate children with different skills and guide them to reach heights in what they are good at

Employees will gain the required capacity to perform their tasks through various sources namely, innate ability, social engagement, formal education, and professional training. Innate ability means the different amounts of skills/human capital due to innate differences. This could be different from the tacit knowledge though. People secure formal education through schools, colleges, and universities. Training is acquired mostly after formal education, often associated with specific skills useful or indispensable for a particular industry. These can be counted as human capital as it has direct correlation with organizational performances. The general supply of workforce is generated through the formal education system. Therefore, it is easy to understand that a mismatch is unavoidable if the demand for workforce is strategically map with the flow of the demand. Reskilling and upskilling may be possible through training, but the development of workforce needs systematic formal education.

\section{Acknowledgments}

We acknowledge contribution by the Accelerating Higher Education Expansion and Development (AHEAD) Operation, a project funded by the World Bank. This paper constitutes of the main research conducted under the AHEAD project namely, Development of a mechanism that leads to a psychological paradigm shift in students' demand and choice for various academic disciplines in the tertiary education in Sri Lanka. 


\section{References}

Alstadsæter, A. (2004). Measuring the consumption value of higher education. Retrieved October 10, 2021, from $\mathrm{http}: / /$ repec.org/esAUSM04/up.17298.1075484224.pdf

CIM. (2015). Marketing and the 7Ps: A brief summary of marketing and how it work. Retrieved October 16, 2021, from https://www.cim.co.uk/media/4772/7ps.pdf

Edirisinghe, L. (2018). Factors Affecting the Choice of Higher Education in Logistics and Transport in Sri Lanka. Colombo, National Centre for Advanced Studies .

Edirisinghe, L. (2020). Leading the Children in Sri Lanka to Right Choice of Education. CINEC Academic Journal, $4(1), 69-73$.

Edirisinghe, L., Ranwaka, L., \& Watsala, D. (2019). Factors Influencing Student's Choice of Academic Disciplines in the Tertiary Education: A Case Study. Colombo, National Centre for Advanced Studies in Humanities and Social Sciences.

Edirisinghe, L., Shen, L., \& Jin, Z. (2018). The Direction of Maritime Education and Training development: A Conceptual Approach. Dalian, Dalian Maritime University.

Edirisinghe, L., Shen, L., \& Wijeratne, A. (2017). Gender Imbalance and Trends in Tertiary Education: A case study in Capacity building in Maritime Industry. Jaffna, University of Jaffna.

Ferrer-Est'evez, M., \& Chalmeta, R. (2021). Integrating Sustainable Development Goals in educational institutions. The International Journal of Management Education, 19, 1-19. https://doi.org/10.1016/j.ijme.2021.100494

IBRD-WB. (2011). Learning for All Investing in People's Knowledge and Skills to Promote Development, Washington: The International Bank for Reconstruction and Development / The World Bank.

IFC. (2017). Private Provision of Education: Opportunities for Emerging Markets, Washington: International Finance Cooperation: The World Bank Group.

Lewis, L. (2013). Is There a Role for the Private Sector in Education?. Retrieved October 8, 2021, from https://blogs.worldbank.org/education/there-role-private-sector-education

Ministry of General Affairs (2021). Closing the gap between education and industry. Retrieved October 6, 2021, from https://www.government.nl/topics/enterprise-and-innovation/closing-the-gap-between-educationand-industry

OECD. (2001). Competencies for Knowledge Economy. Retrieved October 10, 2021, from https://www.oecd.org/innovation/research/1842070.pdf

OECD. (2018). The future of education and skills Education 2030, Paris: Organisation for Economic Co-operation and Development.

OECD. (2019). Education at a Glance - 2019, Paris: Organisation for Economic Co-operation and Development.

Osman, A., Ladhani, S., Findlater, E., \& McKay, V. (2017). Curriculum Framework for the Sustainable Development Goals, London: The Commonwealth-education hub.

Radcliffe, B. (2021). How Education and Training Affect the Economy. Retrieved October 11, 2021, from https://www.investopedia.com/articles/economics/09/education-training-advantages.asp

The World Bank. (2021). Higher Education. Retrieved October 3, 2021, from https://www.worldbank.org/en/topic/tertiaryeducation

UNESCO IESALC. (2021). Report on The Futures of Higher Education Envisions Collective and Holistic Responses to Global Challenges. Retrieved October 5, 2021, from https://www.iesalc.unesco.org/en/2021/05/26/report-on-the-futures-of-higher-education-envisionscollective-and-holistic-responses-to-global-challenges/

UNESCO. (2021). Education for Sustainable Development. Retrieved October 4, 2021, from https://en.unesco.org/themes/education-sustainable-development

UNIDO. (2015). The 2030 Agenda for Sustainable Development:Achieving the industry-related goals and targets, Vianna: United National Industrial Development Organization.

WEF. (2016). The Future of Jobs, Geneva: World Economic Forum.

Wickramasingh, I. P. M., \& Wijenayake, W. (2017). Employability Survey Report Wayamba University of Sri Lanka, Gonawila: Wayamba University of Sri Lanka. 


\section{Copyrights}

Copyright for this article is retained by the author(s), with first publication rights granted to the journal.

This is an open-access article distributed under the terms and conditions of the Creative Commons Attribution license (http://creativecommons.org/licenses/by/4.0/). 